\title{
Jung Teorisi Bağlamında Hasan Ali Toptaş'ın Sonsuzluğa Nokta Romanı Üzerine Arketipsel Bir Okuma
}

\author{
Emine AYAN*
}

\begin{abstract}
$\ddot{O} z$
Analitik psikolojinin kurucusu olarak bilinen Carl Gustav Jung, Sigmund Freud'un öncüsü olduğu psikanalitik kurama katkı sağlayan; ancak 1912 yılında yayımladığı Bilinçdışının Psikolojisi adlı yapıtı ile Freud'un çizgisinden ayrılarak bilimsel serüvenini analitik psikoloji alanındaki çalışmalarıyla sürdüren bir teorisyendir. İnsan zihninin yapısını bilinç ve bilinçdışı olmak üzere iki katmana ayıran Freud'un aksine bilinçdışının yalnızca bastırılmış kişisel olgulardan değil tüm insanlığın ortak deneyimlerine dayalı psişik içeriklerden de oluşabileceğini öne süren Jung, bu bağlamda kolektif bilinçdışı kavramını geliştirir. Jung'un nevrotik bozuklukların kaynağında yer alan olguları kolektif bilinçdışının öğeleri olarak tanımladığı arketiplerle açıkladığı dikkat çeker.

Bu çalışmada 1980 sonrası Türk edebiyatının önde gelen yazarlarından biri olan Hasan Ali Toptaş'ın 1993 yılında yayımlanan ilk romanı Sonsuzluğa Nokta, arketipsel bir okumaya tabi tutulmuştur. Romanda anlatının merkezinde yer alan roman kahramanının nevrotik bir kişilik yapısı sergilediği saptanmıştır. Çalışmada bu durumun altında yatan olgular kolektif bilinçdışının yapıtaşları arasında yer alan benlik, anne, anima, gölge ve persona arketipleri bağlamında analiz edilmiştir.
\end{abstract}

Anahtar Kelimeler: Carl Gustav Jung, kolektif bilinçdışı, arketip, Hasan Ali Toptaş, Sonsuzluğa Nokta, Bedran.

\footnotetext{
* Arş. Gör. Dr., Çukurova Üniversitesi, Fen Edebiyat Fakültesi, Türk Dili ve Edebiyatı Bölümü, Türkiye. Elmek: eayan333@gmail.com. Orcid: 0000-0003-2132-5587
} 


\title{
An Archetypal Reading On The Novel Sonsuzluğa Nokta Of Hasan Ali Toptaş In The Context Of Jung Theory
}

\begin{abstract}
Carl Gustav Jung, known as the founder of analytical psychology, is a theorist contributing to the psychoanalytic theory pioneered by Sigmund Freud; however, in 1912, with the publication of his work Psychology of the Unconscious, he left the Freudian group and continued his scientific adventure with his work in analytic psychology. Unlike Freud, who divides the structure of the human mind into two layers, the consciousness and the unconscious, Jung argues that the unconscious can consist not only of repressed personal phenomena, but also of psychic contents based on the common experiences of all humanity, in this context, Jung develops the concept of collective unconscious. It is taken attention that Jung explains the phenomena at the source of neurotic disorders in archetypes, which he describes as elements of the collective unconscious.

In this study, Sonsuzluğa Nokta, the first novel of Hasan Ali Toptaş, one of the leading writers of Turkish literature after 1980, which was published in 1993, was subjected to an archetypal reading. In the novel, it was determined that the novel character, who is at the center of the narrative, has a neurotic personality structure. In the study, the underlying phenomena were analyzed in the context of self, mother, anima, shadow and persona and spirit archetypes, which are among the building blocks of the collective unconscious.
\end{abstract}

Keywords: Carl Gustav Jung, collective unconscious, archetype, Hasan Ali Toptaş, Sonsuzluğa Nokta, Bedran 


\section{Extended Abstract}

\section{Research Aim}

The aim of this study is to shed light on Bedran's personality structure which is found to exhibit some neurotic behaviors in Sonsuzluğa Nokta within the context of self, mother, anima, shadow and persona archetypes.

\section{Research Questions}

What are the theoretical views of Carl Gustav Jung?

What does archetype mean and what are the effects of archetypes on the psyche as collective unconscious elements?

What are the archetypal themes in Hasan Ali Toptaş's Sonsuzluğa Nokta?

Can Sonsuzluğa Nokta be subjected to an archetypal analysis?

Is Hasan Ali Toptaş a novelist familiar with Jung terminology?

\section{Methodology}

In this study, the novel analysis method has been applied in a scientific framework, and comparisons, interpretations etc. have been used as methods during the analysis.

\section{Research indications}

Sonsuzluğa Nokta focuses on the spiritual adventure of Bedran, who had an unhappy childhood and was bedridden as a result of a traffic accident. In this study, it was found that Bedran exhibited some neurotic behaviors. Considering Jung's psychoanalytic approach, it was found that the space that Bedran feels in the novel can be explained by archetypes. In the novel it is possible to argue that the neurosis in Bedran stems from the destruction caused by the ego of the contents leaking from the collective unconscious to the conscious. The collective unconscious contents that destroy Bedran in the novel are the archetypes of self, mother, anima, shadow and persona.

It is possible to examine the self-complexity that draws attention in Bedran in the context of self-complex mentioned by Jung in the context of self-ar- 
chetype. Bedran could not successfully overcome the individualization process with the effect of the self-complex he experienced and this caused neurosis by causing damage to his ego.

In the study, it is possible to argue that the parent complex is effective in the archetypal context in relation to heredity in the self-confusion in Bedran. Bedran could not gain a self because of the dominant archetype in the unconscious stage. It is seen that mother archetype shaped the relationship between Bedran and his wife in the novel.

Bedran's homosexual tendency can be explained in terms of the anima archetype in the theoretical context in relation to the maternal complex. In the theoretical context, it is possible to argue that a neurotic mood developed in Bedran from the dominant appearance of the anima.

In Sonsuzluğa Nokta the problematic relationship between Bedran and his father is based on the shadow archetype. As it can be understood from the findings reached within the scope of the mother and anima archetype, it is seen that the shadow is reflected to the ego with the dominant output of the anima; therefore, it appears that Bedran clashed with his father in the context of sexual identity. When Jung's theoretical approach is examined, it is possible to say that father authority / pressure plays a restrictive role in Bedran's individualization.

In the novel Bedran's being trapped between Isvan and his father can be explained by the archetype of persona.

\section{Results and Discussion}

In this study in which the novel Sonsuzluğa Nokta was subjected to an archetypal analysis in the light of Carl Gustav Jung's views, it is understood that the novel made the analysis of the archtypes possible. Bedran, who is at the center of the narrative, was found to have a neurotic personality structure in the psychoanalytic context. It was determined that self-problem which is the main subject of the novel was derived from the collective unconscious contents that are the core of Jung terminology of the phenomenon. In the study in which the aforementioned trace was explained with the archetypes of self, mother, anima, shadow and persona, it was concluded that Hasan Ali Toptaş had mastered Jung terminology and shed light on the problem of self in an archetypical theoretical framework. 


\section{Giriş}

20. yüzyılın önde gelen düşünürlerinden Carl Gustav Jung (1875-1961), "insan ruhunun daha iyi ve daha anlaşılır bir şekilde kavranmasına" (Jung 1952: 13) çaba gösteren bir teorisyendir. 1907'de karşılaştığ1 Freud ile arasındaki etkileşimin ardından 1912 yılında yayımladığı Bilinçdışının Psikolojisi adlı yapıtı ile Freud'un çizgisinden ayrılan Jung, kurucusu olduğu analitik psikoloji alanındaki çalışmalarını sürdürmüştür.

Freud'un “ruh”a ilişkin görüşlerini zenginleştiren Jung'un “libido”yu sadece cinsel enerji olarak değil ruhsal enerjinin bütünü olarak kabul ettiği (Ukray 2015: 11), ödipal komplex sürecini reddettiği (Ukray 2015: 15) ve nevrozları yalnızca cinsellikle değil insandaki ruhsal süreçle de ilintili kılarak irsî olana dikkat çektiği görülür. Jung, Freud'un bastırılmış cinsel ve kişisel içerikler olarak alımladığı bilinçdışını "kocaman tarihsel bir depo" (Jung 1982: 162) addetmiş ve "bilinçli olmayan yani Benle algılanabilir şekilde bir ilişsisi bulunmayan bütün psişik içerikleri veya süreçleri kapsayan psikolojik bir sınır çizgisi kavramı” (Jung 2016: 14) olarak tanımlamıştır. Jung'un bu kavrama bakışını Fordham (2011) şöyle özetlemektedir:

Jung'ın bilinçdışına bakışı, bilinçdışını yalnızca, içimizdeki hoş karşılanmayan, çocuksu, hatta vahşice ve unutmak istediğimiz her şeyin kaynağı olarak kabul eden görüşten daha olumludur. Bütün bu özelliklerin bilinçdışı oldukları gerçektir ve bunlardan bilincin içinde beliren görüntüler de karmaşık ve biçimsizdir. Ancak, bilinçdışı bilincin de biçimlendiricisidir ve yeni yaşam olanaklarının tohumları onun içinde bulunmaktadır. Ruhun bilinç yönü, denizde yükselen bir adaya benzetilebilir. Biz yalnızca onun su üzerinde kalan bölümünü görürüz. Fakat çok daha büyük, bilinmeyen, bir gerçeklik aşağıda bulunmaktadır ki bunu bilinçdışına benzetebiliriz (24).

Bilinçdışını psişik süreçlerin merkezine alan yaklaşımı ile Freud'dan beslenen; ancak ondan "id, ego ve süperego mekanizmaları yerine bilinç, kişisel bilinçdış1 ve kolektif bilinçdışı olmak üzere üç boyutlu bir yapı”yı (Ukray 2015: 17-18) benimsemesi ile ayrılan Jung (2016), bilinci "psişik içeriklerin Benle ilişkisini sürdüren işlev veya faaliyet” (14) olarak tanımlar. Jung’un (1982) ifadesiyle bilinçdış1 
ülke kesintisiz uzayıp giden devcileyin boyutlarla donatılmıştır; ancak bilinçli ülke sürekli algılama ve kavramalarımızın her an yeniden oluşturduğu sınırlı bir alana benzer (6). Kişisel bilinçdışının Freud'un bilinçdışı kavramı ile özdeş olduğunu öne süren Jung, bilinçdışının "insanın yalnızca eskilerini attığı bir bodrum odası değil, bilincin ve insanlığın yaratıcı ve yıkıcı ruhunun kaynağı” (Fordham 2011: 32) olduğu düşüncesiyle kolektif bilinçdışını keşfetmiş ve bu bağlamda "tek bir bireye değil, . . insanlığa ait bütün psişik içerikler"e (Jung 2016: 49) odaklanmıştır. Kolektif bilinçdışı "bilinçdışının, bireysel bilinçdışından daha derinlerde olan bir bölümü" (Fordham 2011: 27) olup "doğuştan gelen köksel imgeleri (anatipleri) kapsamaktadır ve bu imgelerde, doğuş halindeki insanlığın bazı temel durumlar karşısında yaşadığı ortaklaşa deneyim yoğunlaşmış olarak bulunmaktadır" (Ukray 2015: 249). Jung'a göre "insan zihni, onun evrimi tarafindan biçimlendirilmiştir. Dolayısıyla bireyin varoluşu . . . yalnızca kişisel geçmişini değil, kendi türünün geçmişini, hatta insanlığın evrimini içerir" (Ukray 2015: 255). Kolektif bilinçdışı "geçmişten gelen ... genler yoluyla devralınan ortak bilinçdışı" (Ukray 2015: 18) oluşu itibariyle kalıtımsal bir nitelik taşımaktadır:

Bunu ruhsal kalıtım olarak da adlandırabiliriz. Burası bir tür olarak edindiğimiz tüm deneyimlerin depolandığı yerdir; hepimiz bu bilgiyle doğarız. Yine de hiçbir zaman doğrudan bunun bilincinde olamayız. Burası tüm deneyimlerimizi ve davranışlarımızı etkiler, en çok da duygusal olanları. Fakat biz bunu ancak dolaylı olarak, etkilerini görerek anlayabiliriz (Ukray 2015: 122-123).

Jung teorisinde kolektif bilinçdışı arketip adı verilen çeşitli öğelerden oluşur. "Illk örnek" (TDK 2005: 121) anlamına gelen ve Jung'un (2016) "ilksel imge" de (41) dediği arketip, "insan kültürünü oluşturan temel yapı taşı" (Ukray 2015: 103) olup Platon'un 'idea'sıyla eşanlamlıdır (Jung 2017: 17). Arketipler içgüdülerle eşdeğerdir; ancak cinsel değil ruhsal bir yön içerirler. Jung'un "insanların ortak bilinçdışında yatan ... psişik davranış formları" (Moran 2008: 224) olarak tanımladığı arketipler, "doğuştan getirilen evrensel imgeler" (Ukray 2015: 142) olup "insanın insan olma evresine ulaşmadan önce geçmişinden getirdiği gizli bellek kalıntıları"nı (Ukray 2015: 114) içerir. "Durmadan tekrarlanan psişik deneyimlerin çökeltisi, dolayısıyla tipik temel biçimi” (Jung 2016: 41) olarak arketipler "her zaman kolektiftir" (Jung 2016: 41). Jung'a (1982) göre bilinçdışı incelendiğinde ulaşılabilecek en derin katman insanın insanlıkla kaynaştı̆̆ katman olup nasıl ki insan iki göz, iki kulak, bir kalp vb. ile aynı vücudu taşıyor, yalnızca 
bireyden bireye ufak ayrılıklar gösteriyorsa ruhsal bakımdan da insanlar arasında aynı temel uygunluk bulunmaktadır (48). Dolayısıyla arketipler kolektif bilinçdışı ile ilintili olarak evrensel bir nitelik taşımaktadır.

Arketipleri nevrozların kaynağında yer alan kalıtımsal kolektif bilinçdışı içerikler olarak düşünmek mümkündür. Nitekim Jung (1982) kolektif bilinçdış1nın içerikleri etkin duruma geçtiğinde insanlarda tuhaf davranışlarla karşılaşıldığını (52) ifade etmektedir. Nevrozu "kendi kendine acı çeken kişinin yaşantısına ve sık sık da sağlığına karışmış bir çeşit özel ruhsal tedirginlik" (Fordham 2011: 117) olarak tanımlayan Jung, arketiplerin etkisinde kalma olayını 'şişme' [inflation] olarak adlandırmakta ve etki altında kalan kişinin kendisine göre çok büyük ve tamamen kolektif nitelikteki bir şey tarafından 'şişirildiğini' (Fordham 2011: 78) belirtmektedir. 'Şişme' "kolektif bilinçdışından gelen bir istila hareketi”yle oluşmakta (78) ve egoda yıkıcı bir etki bırakmaktadır. Jung'un görüşlerini özetleyen Fordham'ın (2011) deyimiyle ego kendisine kolektif bilinçdışı içerikler katmaya çalışırsa fazla yüklenmiş bir geminin batması gibi yok olma tehlikesine girmektedir (79).

Bu çalışmada Sonsuzluğa Nokta romanında birtakım nevrotik davranışlar sergilediği saptanan Bedran'ın kişilik yapısından hareketle bu davranışların altında yatan olgulara Jung terminolojisinde kolektif bilinçd1şı içeriklerin ifadesi olan benlik, anne, anima, gölge ve persona arketipleri bağlamında 1şı tutulmuştur. Yapılan literatür taramasında Esra Sazyek'in (2013) kaleme aldığı Jung Işığında Heba adlı çalışmanın dışında doğrudan Hasan Ali Toptaş'ın eserlerine arketipsel bağlamda 1şık tutan başka bir çalışmaya rastlanmamıştır.

\section{Sonsuzluğa Nokta Romanı Üzerine Arketipsel Bir Okuma}

1980 sonrası Türk edebiyatının tanınmış yazarlarından biri olan Hasan Ali Toptaş, kendisini edebiyata adayan ve bu uğurda 'yazma'yı bir tür yaşam biçimi haline getiren sanatsal kişiliği ile dikkat çekmektedir. "Harflerle beslenip harflerle var olabilen" (Tokay 2013: 103) bir yazar olarak Toptaş’ın hayatın anlamına ancak yazı yolu ile erişebildiğini ve yazmadığı ya da yazamadığı zaman kendisi olamadığını (Ecevit 1996: 159) ifade ettiği görülür. Yazarlığı bir meslekten ziyade tepeden tırnağa kişiliği ilgilendiren çok özel bir uğraş (Varlık 2005: 277) addeden yazar için "harfler âlemi . . . bir tür sığınak" (Dönmez 2005: 200); yazı ise harflerden oluşan bir müzikal inşadır: 
Her harf bir sesi temsil ettiğine göre, doğal olarak her cümlenin bir müziği vardır. Cümlelerin toplamı da metnin müziğini oluşturur. Biz hiç umursamasak bile neticede bir müzik oluşur. Bu konu benim yazı hassasiyetlerimden biridir. . . Ayrıca, harflere ben sadece ses olarak da bakmam; onlar birer canlıdır benim gözümde. Elbette, kelimeler de canlıdır ve kelimeler sadece sözlükte dururken aynı gramajdadır; sözlükten çıkarıp kullandığımızda her birinin ağırlığı kullandığımız yere göre değişir ve birer canlı gibi hareket etmeye başlarlar (Öztunç 2013: 80).

Çocukluk döneminde başının arka tarafında çıkan bir yara yüzünden kendisine aynalı lakabını takan kasabalıdan (Toptaş 2019: 30-31) kurtulmak için kitapların dünyasına sığınan (Karaduman Okay 2006: 210) Toptaş’ın ilk kalem denemesi Orhan Kemal'e öykünerek yazmaya başladığı ve adını “ya Tahammül Çemberi ya da Esrar Kumkuması" (Varlık 2010: 64) koyduğu yarım kalmış bir romandır. İki şiiri 1983 'te Yarın dergisinde (Baran 2009: 87), birkaç şiiri de Çiğdem Duru adıyla çeşitli dergilerde yayımlanan (Kurt 2011: 267) Toptaş, şiiri “anlatı sanatının çekirdeği” (Korat 2007) saymış; edebi faaliyetine yazdığı öykülerle devam etmiştir. Yazın dünyasına 1987 yılında yayımlanan Bir Gülüşün Kimliği adlı öykü kitabı ile atılan yazarın edebi serüveni 1993 yılında basılan Sonsuzluğa Nokta romanı ile devam etmiştir. Yazarın bu romanını Gölgesizler (1994), Kayıp Hayaller Kitabı (1996), Bin Hüzünlü Haz (1998), Uykuların Doğusu (2005), Heba (2013), Kuşlar Yasına Gider (2016) ve Beni Kör Kuyularda (2019) adlı romanları takip etmiştir. Romana geçişini bu türü daha çok sevmesinin yanı sıra yayın dünyasıyla olan ilişkisini en aza indirme (Duman-Çelik 1998: 121) çabası olarak açıklayan Toptaş, romanı romanın içinde düşünebilen (Gümüş 2013: 61) bir yazardır:

Belirlenmiş bir güzergâhta yol almaktan, belirlenmiş bir hedefe doğru yürümekten hoşlanmıyorum. Güzergâhın ve hedefin sadece benim aklımla belirlenmesini de istemiyorum ayrıca, metnin iç aklı dediğimiz aklın da bu konuda söz sahibi olmasını istiyorum. Baştan planlanan romanla benim romanım aynı yere gitmez bu durumda; ikisi de (biri metnin içinde, diğeri dışında) planlanmış ve en ince ayrıntısına kadar hesaplanmış olur ama benim romanım heyecanla yazılmış ve yoldan çıkmalardan pay almış olur. Bir de daha önemlisi, ben onu yazarken benim romanım da beni yazmış olur (Gümüş 2013: 61).

Sonsuzluğa Nokta, mutsuz bir çocukluk dönemi geçiren ve bir trafik kazası sonucu yatalak kalan Bedran'ın ruhsal serüveni üzerine odaklıdır. Roman kahramanının taşradan kente doğru yol alırken zihninden geçenlerle açılan anlatı, 
bir benlik arayışının öyküsüdür. Silsile halinde akan bir olay örgüsünden ziyade bir bütünü oluşturan parçaların romanın çeşitli yerlerine serpiştirildiği anlatıda, okur, bir yandan Bedran'ın sakat kalmadan önce şehirde aynı evi paylaştığı Turan ve İsvan ile ilişkisine, başarısızlıkla sonuçlanan iş ve aşk deneyimlerine ve evliliğine ilişkin bilgilere ulaşırken öte yandan geçirdiği trafik kazasının ardından içine düştüğü bunalıma tanık olur. Çocukluğunun geçtiği taşra atmosferine uyum sağlayamadığı için çareyi şehre kaçmakta bulan Bedran, şehir hayatında da dikiş tutturamamış, karısı ile evliliği yolunda gitmemiştir. Bir zamanlar baba diye binlerce, yüzbinlerce kez seslendiği halde bir türlü ısınamadığı babasının gölgesinde nasıl küçülerek büyüdüyse karısının gölgesinde yaşayarak öldüğünü düşünen Bedran'ın (Toptaş 2014: 157) romanın sonunda karısı tarafından terk edildiği ve ölümle yüz yüze geldiği görülür.

Bilinçdışından yansıyan bir iç bunaltısının anlatının bütününe sirayet ettiği romanda, Bedran, içinde hissettiği boşlukta adını veremediği, derinliğini bilemediği, sürekli büyüyen ve bütün dünyasını karartan korkularıyla (Toptaş 2014: 11) boğuşmakta ve ne yapsa bu boşluğu dolduramamaktadır. Bedran'da nevrotik bir semptom olarak dikkat çeken bu durumun altında yatan etkenler Jung'un psikanalitik yaklaşımı doğrultusunda düşünüldüğünde etkin duruma geçerek bilinci istila eden kolektif bilinçdışı içeriklerle; dolayısıyla da arketiplerle açıklanabilir niteliktedir.

Bilinçli zihnin bilinçdışı bir ruhtan ortaya çıkıp büyüdüğünü (Fordham 2011: 18) ifade eden Jung, cinsel içeriği olmayan istek ve dürtülere karşıllk gelen libidonun (Fordham 2011: 20) bir gelgit hareketi içinde olduğunu ifade etmiş; bilincin isteklerini yerine getiren ileriye doğru hareketi ilerleme, bilinçdışının isteklerini karş1layan geriye doğru hareketi ise gerileme olarak adlandırmıştır. Jung'a göre libidonun giderek ileriye doğru bir harekete dönüşmesi süreci işledikçe gerileme olayı ilerlemenin normal bir karşıt kutbudur; ancak ileriye doğru hareket olanaksızlaştığında libido bilinçdışına doğru aktığından (Fordham 2011: 21) aşırı enerji ile yüklenen bilinçdışı kendisine bir çıkış yolu arayarak bir fantezi ya da bir çeşit nörotik belirti biçiminde bilince sızmakta ve bilinçdışının bilince tümüyle egemen olabildiği durumlarda ortaya şiddetli bir patlama ya da psikoz çıkmaktadır (Fordham 2011: 22). Bu doğrultuda romanda Bedran'daki nevrozun kolektif bilinçdışından bilincine sızan içeriklerin egosunda yarattığı yıkımdan kaynaklandığını iddia etmek mümkündür. Psikozu bir barajın patlaması ve bütün toprakla- 
rın sel altında kalmasına benzeten Jung (Fordham 2011: 22), insanın kendisiyle ve çevre koşullarıyla uyum içinde olmasının gerekliliğine (Fordham 2011: 22) işaret ederek en aşırı olaylarda libidonun kendisine bir çıkış yolu bulamadığında yaşamdan kopmalar olduğuna (Fordham 2011: 22) dikkat çekmektedir. Romanda kendisini 'dönüp duran paslı bir çember' olarak algıladığı toplumda yelken kulaklı bir uyumsuz (Toptaş 2014: 118) addeden Bedran'ın içinde bulunduğu psikozu en üst sınırda yaşayarak romanın sonunda yaşamına son verme aşamasına geldiği görülür. Bedran'daki bu durumun Jung terminolojisindeki karşılığı "şişme' [inflation]"dir. Romanda Bedran'1 yıkıma uğratan kolektif bilinçdışı içerikler ise benlik, anne, anima, gölge ve persona olarak belirmektedir.

Sonsuzluğa Nokta romanında Bedran'ın döne dolaşa her sokakta, her köşede, her kıpırtıda ve her seste kendini aradığı (Toptaş 2014: 105); dolayısıyla bir benlik karmaşası yaşadığı görülür. Nevrozu "insan ruhundaki birtakım karmaşaların yol açtığı kişilik bölünmesi” (217) olarak tanımlayan Jung (1982), insandaki birbiriyle uyuşmaz nitelikteki komplekslerin kişilik bölünmesine yol açtığını ve bu durumda kişiliğin her bir parçasının kendi bağımsız yaşamını sürdürerek ortada bunları bir araya getirecek kişilik diye bir şeyden eser kalmadığını (217) ifade etmektedir. Romanda Bedran'1n bir ruhsal bölünme yaşadığ 1 ve benliğinden kopan her bir parçanın nevrotik bir semptom ile varlığını sürdürdüğü görülür. Kasabadan kente doğru yaptığ 1 yolculuk esnasında geride zamanları, özlemleri ve tutkuları ayrı, binlerce, milyonlarca Bedran bıraktığını (Toptaş 2014: 8) duyumsayan Bedran’ın geçmişsinde yutulmuş olan bir kendiliğin arayışında taşradan kente kaçtığı; ancak geçmişinin otobüsten indiği anda muavinin eline tutuşturduğu gizemli bir bavul şekline bürünerek onu yakaladığı (Güçbilmez-Yılmaz, 2010: 189) görülür. Dolayısıyla romanda Bedran'ın benlik çabası başarısızlıkla sonuçlanmıştır:

Bedran, asla dönmemek üzere kasabadan kente gelir kaçarcasına fakat anasının yanına koyduğu bavul aynalardan yansıyan Bedranlar babasının elleri dayısının bıyıkları yakasını bir türlü bırakmaz. Taşranın tüm sıkıntılı iç boğucu anıları o hiç açılmayan bavulun içinde Bedran ile birlikte sürüklene sürüklene gelir kente, unutulmak istenseler de. Zincirleri onu hep kentin yaşamından uzaklara düşürür hep bambaşka dünyalara götürür ve hatta yatağa bile bağlar Bedran'1 sonunda. Ne kentte nefes alabildiğini hisseder ne taşrada. Aralarda bir yerlerde yaşar sürekli, İçinden asla çıkamayacağını düşündüğü döngü anılarla birlikte çöreklenip oturur kendi sonsuzluğuna, çokluğuna. (Kale 2006) 
Bedran'da dikkat çeken karmaşayı Jung’un (2016) sözünü ettiği “benkompleksi" (13); dolayısıyla da benlik arketipi bağlamında irdelemek mümkündür. Benden bilinç alanının merkezini oluşturan, büyük ölçüde sürekliliği ve kimliği bulunan fikirler kompleksini anlayan (13) Jung (2016), ben-kompleksinin bir bilinç durumu olduğu kadar bilincin de içeriğini oluşturduğunu (13) ifade eder. Bireylikle bireyin psikolojik olarak her bakımdan kendine özgülügüunü ve tekilliğini kasteden (18) Jung’a (2016) göre “bireylik bilinçdışıysa psikolojik açıdan birey yoktur, ama kolektif bilinç psikolojisi vardır" (17). Romanda Bedran'ın onca çabasına; hatta doğduğu, büyüdügü kasabayı terk etme pahasına göze aldığ 1 benlik çabasının boşa çıkışı, kolektif bilinçdışının bilinç üzerindeki baskısından kaynaklanır. Bu noktada devreye benlik arketipinin girdiğini iddia etmek mümkündür. "Kolektif bilinçdışının merkez arketipi” (Ukray 2015: 144) olan ve bilinçdışındaki diğer arketiplerin bilinç düzeyinde ortaya çıkışlarını düzenleyip örgütleyerek kişiliği bütünleştirme (Ukray 2015: 154) işlevini üstlenen bu arketip, egonun uyumunda önemli bir rol oynamaktadır. Bedran'ın uyumsuzluğunu bu bağlamda değerlendirmek mümkündür. Bedran, yaşadığg ben-kompleksinin etkisi ile bireyleşme sürecini başarı ile atlatamamış ve bu durum egosunda hasara yol açarak nevroza neden olmuştur.

Romanda Bedran'ın annesi ve babası ile sorunlu bir ilişki içinde olduğu görülür. Ana-babanın bilinçdışı etkisinin çocuğun karakterinin biçimlenmesinde etken olacağı kanısını taşıyan Jung, bilhassa 'uyumsuz çocuklar' olarak bilinen sorunlu çocukların ana-babalarına dikkat çekmektedir (Fordham 2011: 147). Kalıtıma önem veren ve insanın önceden biçimlenmiş türüne uygun bir psikeye sahip olup belirgin ailevi özellikler taşıdığı varsayımından yola çıkan (20) Jung’a (2017) göre bilinçdışı olsa da her psikedeki aktif yap1 ve biçimler; düşünceleri, duyguları ve eylemleri içgüdüsel olarak önceden biçimlendirir ve etkiler (20-21). “Aktif yapı ve biçimler” ile arketipleri kastettiği anlaşılan Jung (2017), arketiplerin "her zaman ve her yerde herhangi bir dış etkenden bağımsız olarak kendiliğinden yeniden ortaya çıkabileceklerini” (20) savunur. Bu doğrultuda irdelendiğinde Bedran'daki benlik karmaşasında kalıtımla ilişkili olarak arketipsel bağlamda anne-baba kompleksinin etkili olduğunu iddia etmek mümkündür.

Jung'un (2017) erken çocukluk evresine dek uzanan nevrozlarda rahatsızlığın oluşumunda annenin daima aktif bir rol oynadığını (24) ifade ettiği ve 
anne kompleksinin temelini anne arketipine dayandırdığı görülür. Erkek çocukta eşcinsellik, Don Juanizm, bazen de iktidarsızlık olarak tezahür eden bu kompleksin (25) oluşumunu Jung (2017) şöyle özetlemektedir: "Eşcinsellikte heteroseksüel unsur bilinçdışında anneye bağlanmıştır ... . Müstakbel erkeğin karşılaştığ 1 ilk dişi yaratık annedir ve anne, açıkça ya da gizlice, kabaca ya da nazikçe, bilinçli ya da bilinçsiz, oğulun erkekliğini ima etmeden duramaz; oğul da annenin dişiliğinin giderek farkına varır ya da en azından bilinçsizce, içgüdüsel olarak buna yanıt verir. Böylece, oğulda, kimlikle ya da kendini farklılaştırmaya dirençle ilgili basit ilişkiler erotik çekim ya da itmenin faktörleriyle sürekli iç içe geçer" (25). Jung (2017), erkekteki anne kompleksinin oğulda doğal olmayan bir cinselleşmeyle eril içgüdülerin zedelenmesine yol açtı̆̆ını saptamıştır (25). Romanda Bedran'ın kentte iken aynı evi paylaştığı gençlerden biri olan İsvan'a karşı sergilediği eşcinsel eğilimi bu kompleksin bir tezahürü olarak ele almak mümkündür. Jung teorisinde başlangıçta annesi ile tam bir ortaklık, bilinçdışı bir özdeşleşme içinde olan çocukta ben bilincinin uyanmasıyla bu ortaklığın yavaş yavaş ortadan kalkmas1 ve böylece ben ve anne ayrımının oluşması (Jung 2017: 38) beklenir; ancak Bedran'da bu sürecin başarısızla sonuçlanmasından dolayı eşcinsel bir eğilimin belirdiğini iddia etmek mümkündür. Bu durum "bilinçdışı evrede anne imgesinin baskın olmasından kaynaklanan psişik bir olgu"nun (Jung 2017: 41) sonucu olup Freud'un da oedipus kompleksinden söz ederken üzerinde durduğu "özdeşleşme" (Eagleton 2011:164-165); dolayisıyla da toplumsal bir cinsel kimlik edinme sorunu ile doğrudan ilişkilidir. Nitekim arketipin gücünün en yoğun hissedildiği ruhsal deneyim alanı olan özdeşleşme evresi aynı zamanda "birey olmanın, kendi olma deneyiminin yaşandığı alan"dır (Jung 2017: 42). Bedran'ın bu evreyi başarı ile atlamadığı ve bilinçdışı evrede baskın çıkan anne arketipi dolayısıyla benlik kazanamadığı görülür.

Romanda İsvan'ın ölümünden sonra Gülderim ile evlenen ve evliliğinin temeli düğün günü annesinin akıttığı gözyaşları ile atılan (Toptaş 2014: 26) Bedran'ın, annesi olmadan hareket edemeyeceğini duyumsaması bilinçdışı düzlemde baskın çıkan anne arketipinin Bedran'ın tüm yaşamına sirayet eden bir yansısıdır. Romanda Bedran'ın karısı ile arasındaki ilişkiyi de bu arketipin şekillendirdiği görülür. Düğün günü kollarının arasında pembe pembe gülümseyen karısı (Toptaş 2014: 25) karşısında kendisini “mutlu olmaya mahkûm” (Toptaş 
2014: 26) hisseden Bedran, içten içe İsvan'1 anımsamakta, mutsuzluğunun ve yalnızlığının yanı sıra hiçbir zaman bir başkasının yerine geçtiğini öğrenemeyecek olan karısı ile İsvan'la birlikte olamayacağı için evlendiğini düşünmektedir (Toptaş 2014: 27). Evliliğinin ilk yıllarında kısa süren bir mutluluğun ardından bilhassa yatalak kaldıktan sonra mutsuz bir kadına dönüşen karısı ile arasında büyük bir uçurum açılan Bedran'ın cinsel iktidarsızlığı da anne arketipinin bir izdüşümüdür. Karısına tam karşılık verip onu şaşırtacakken bakışlarının tepesindeki ampulün tozlarına takılmasıyla her şeyin kararması (Toptaş 2014: 81) İsvan ile doğrudan ilişkilidir. Bedran'ın eşcinsel eğilimine işaret eden bir metafor olarak düşünebilecek olan “tozlu ampul” o an Bedran'a kadın tenli İsvan’1 anımsatmıştır.

Bedran'ın sergilediği eşcinsel eğilim anne kompleksi ile ilişkili olarak kuramsal bağlamda anima arketipi ile açıklanabilir. Fizyolojik olarak bir kişinin gerçekte iki cinselli olduğunu (Ukray 2015: 115) savunan Jung, animayı erkeklerin kolektif bilinçdışındaki dişi yanı; animusu ise erkil yanı (Ukray 2015: 128) olarak tanımlar. Bu iki arketip aşk hayatı ile ilgili olup uyum sürecini etkiler. Jung, "erkeğin bilinçdışında kadının kolektif bir imajının var olduğunu ve onun bu imaj yardımıyla kadının doğasını kavradığını" (Fordham 2011: 68) iddia eder. Anne arketipi ile bağlantılı olarak bir erkeğin kendisini biçimlendirmede ve etkilemede yaşadığı en güçlü deneyimin annesi ile olduğuna (Fordham 2011: 68) dikkat çeken Jung'un teorisinde annesinin etkisinden kurtulamayan erkekte cinsel kimlik problemine dayanan bir nevroz gelişir. Sözü edilen teorik yaklaşımda "kendisini animasına kaptırmış bir erkek denetlenemez duygulara yem olur" (Fordham 2011: 71). Kuramsal bağlamda irdelendiğinde Bedran'da animanın baskın çıkışından kaynaklı nevrotik bir ruh halinin geliştiğini iddia etmek mümkündür. Romanda taşıdığı kadın ruhu gün yüzüne çıkan Bedran’ın aynaya bakıp kendisini bıyıklı gördüğünde uyuştuğunu ya da düpedüz öldügünü (Toptaş 2014: 103) hissetmesi bu bağlamda dikkat çekmektedir. Anlatının özsel atmosferi içerisinde "bıyık" Bedran'ın kimlik karmaşasına işaret eden bir tür metafor olarak düşünülebilir.

Sonsuzluğa Nokta romanında Bedran'ın babası ile arasındaki sorunlu ilişkinin kaynağı gölge arketipine dayanır. İnsanın kendi cinsiyetini temsil eden ve kendi cinsinden olan kişilerle ilişkilerini düzenleyen arketipe gölge adını veren Jung (Ukray 2015: 116), bu arketipi “egonun karanlık yüzü” (Ukray 2015: 126) addeder. Ona göre “ego ve gölge işbirliği yaptıklarında kişi kendini yaşam dolu 
hisseder, zihinsel işlevleri canlanır, bedensel etkinlik artar. Kişi bunalıma girdiğinde ise gölge ego üzerinde denetim kurmaya çalışır” (Ukray 2015: 87). Birleşme sürecinin temel düzeneğini bilinç ve bilinçdışının karşılıklı eyleşimi olarak gören Jung'un kişinin kendi merkezine doğru büyük yolculuğunu tarif ederken başvurduğu referanslar arketipsel semboller (Saydam 2017: 13) olup "bu süreç kapsamında bireyin öncelikle tanışması ve entegre etmesi gereken arketipsel öğe 'gölge'sidir" (Saydam 2017: 13). Buna göre "gölgeye bilincin yansımasıyla karanlıkta kalan aydınlığa alınır. Daha ileri aşamada cinsiyetlerarası ötekiliğin de çözümleneceği ve aşılacağı bir karşılaşma belirleyicidir. Erkek bilinçdışında bütünleyici öğe olarak yer alan dişi imgesi ('anima’) ile tanışır”' (Saydam 2017: 13).

Anne ve anima arketipi kapsamında ulaşılan tespitlerden de anlaşılacağı üzere Bedran'da söz konusu entegrenin gerçekleşemediği; animanın baskın çıkışı ile gölgenin egoya yansıdığı; dolayısıyla da Bedran'ın cinsel kimlik bağlamında babası ile çatıştı̆̆ 1 görülür. Bedran nevrotik bir ruh hali içinde olduğundan gölgesi egosunu baskılamakta; eşcinsel eğilimi ile içinde bulunduğu baba kompleksinin etkisi altında "bir otorite figürü" (Ukray 2015: 128) olarak beliren baba imgesinin kendisine yüklediği erkeklik güdüsü arasında bocalamaktadır. Bedran'ın babasına benzemekten kaçınması bu bağlamda dikkat çekicidir. Babasının kendisinde süregeldiğini kabullenemeyen (Toptaş 2014: 100) Bedran, babasından kurtulma isteği içindedir.

Jung'un kuramsal yaklaşımı doğrultusunda irdelendiğinde baba otoritesinin/baskısının Bedran'ın bireyleşmesini ketleyici bir rol oynadığını söylemek mümkündür. Bedran'da da baştan beri vurgulandığı üzere bir benlik sorunu söz konusudur. Çocukluğu şoför olan babası ile aralarında geçen tatsız anılarla örülü olan Bedran'ın, gölgesinde yaşamaktan bıktığı babasından kurtulup varlığını ispatlama inancı ile kente kaçtığı; ancak babasının gölgesinin peşini bırakmadığı görülür. Sözgelimi kentte taksisine bindiği şoförü babasına benzeten Bedran, birdenbire çocukluğuna dönüp babası ile ilişkisini yeniden yaşayarak üzülüp kahrolma ve kederli bir geçmişin karanlığına saplanıp kalma korkusu ile bir süre nereye gideceğini söyleyemez (Toptaş 2014: 60-61). Çocukluğu boyunca hep babasının gidişlerini gören (Toptaş 2014: 62) Bedran'ın sürekli olarak babasının kötü muamelesine maruz kaldığ için kendini öldürmeyi bile tasarladığı (Toptaş 2014: 68); ancak çaresizliği ve yetersizliği yüzünden bunu beceremediği (Toptaş 2014: 68) görülür. Günün birinde kendisini bulacağını umut eden Bedran, bütüncül bir benliğe ulaşamaz. 
Romanda bir yandan İsvan'ın karanlıkta ay ışı̆̆ını dalgalandırarak 1lık bir süt gibi akan sesine tutunup derin bir uykuya dalmak isteyen (Toptaş 2014: 117); öte yandan babasının 'herkes gibi olamadın gitti!' deyişi kulaklarından gitmeyen (Toptaş 2014: 117) Bedran'ın kendisini ikisi arasına gerilmiş bir ip gibi hissetmesi (Toptaş 2014: 175) persona arketipi ile açıklanabilir. Dışa yönelik yüze persona, içe yönelik yüze anima adını veren (58) Jung (2016), personanın işlevinin ruhsal bütünlüğün sağlanması açısından gölgeyi denetim altında tutmak (Ukray 2015: 143) olduğunu; bu iki yapı arasındaki dengeye ait sorunların cinsel kimlik bozukluklarından kişilik bozukluklarına dek çok farklı psikiyatrik bozukluklara yol açabileceğini (Ukray 2015: 12) ifade eder. Ona göre hayatta oynanmak zorunda olunan dişi ya da erkil rol personanın bir parçasını oluşturur (Ukray 2015: 127). Dolayisiyla romanda Bedran'daki toplumsal cinsiyet krizi personanın işlevini yerine getirememesinden kaynaklı nevrotik bir durumdur. Personanın karakterini tamamlayan animanın, cinsel karakteri de etkilediğini (59) savunan Jung (2016), aynı zamanda insanın toplumsal çevresi ile uyumlu bir ilişki sürdürebilmesi için de bu arketipin önemine dikkat çekmektedir. "Toplumun onayını sağlamak amacıyla, bireyin dış dünyaya karşı taktığı maske ya da takındığı kimlik" (Ukray 2015: 115) olan persona, çağdaş yaşam içerisinde var olabilmek ve bu yaşama uyum sağlayabilmek (Ukray 2015: 143) için gereklidir. Ayrıca "toplum her bireyin kendisine düşen rolü mümkün olduğunca kusursuz oynamasını bekler (Fordham 2011: 62). Romanda toplumsal normlara karş1 sergilediği tutum ve davranışları ile dikkat çeken Bedran'ın 'kocaman bir uyumun parçası”" (Toptaş 2014: 137) olmaktan duyduğu rahatsızlık ile girdiği hiçbir işte dikiş tutturamaması persona arketipinin doğurduğu bir sorundur.

\section{Sonuç}

Carl Gustav Jung'un 1şı̆̆ında Sonsuzluğa Nokta romanının arketipsel bir analize tabi tutulduğu bu çalışmada anlatının merkezinde yer alan ve psikanalitik bağlamda nevrotik bir kişilik yapısı sergilediği anlaşılan roman kahramanının tutum ve davranışlarının altında arketipsel olguların yer aldığı saptanmıştır. Romanda temel izlek olarak belirlenen benlik probleminin kaynağında Jung terminolojisinin çekirdeği konumundaki kolektif bilinçdışı içeriklerin; dolayısıyla da arketiplerin etkili olduğu belirlenmiştir. Sözü edilen izleğin benlik, anne, anima, 
gölge ve persona arketipleri ile açıklandığı çalışmada Hasan Ali Toptaş'ın Jung terminolojisine hâkim olduğu ve benlik sorunsalına arketipsel bir kuramsal çerçevede ışık tuttuğu sonucuna ulaşılmıştır. 


\section{Kaynakça}

Baran, Ethem (2009). Tamamlanan metin eksiktir. L. Cantek (Ed.), Başlarken Yalnızsın, Bitirdiğinde Daha da Yalnız (s. 83-94) içinde. İstanbul: İletişim.

Dönmez, Yelda (2005). Sadece iyi romanlara ulaşmak istiyorum. L. Cantek (Ed.), Başlarken Yalnızsın, Bitirdiğinde Daha da Yalnız (s. 199-207) içinde. İstanbul: İletişim.

Duman, Suat; Çelik, Burak (1998), Yazdığım her romanla romanı yeniden tanımlamaya çalış1yorum. L. Cantek (Ed.), Başlarken Yalnızsın, Bitirdiğinde Daha da Yalnız (s. 119-121) içinde. İstanbul: İletişim.

Eagleton, Terry (2011), Edebiyat Kuramı, çev. Tuncay Birkan, İstanbul: Ayrıntı Yayınları, 3. bs.

Ecevit, Yıldız (1996). Roman Yazan Bir Şair. L. Cantek (Ed.), Başlarken Yalnızsın, Bitirdiğinde Daha da Yalnız (s. 159-168) içinde. İstanbul: İletişism.

Fordham, Frieda (2011), Jung Psikolojisinin Ana Hatları, çev. Aslan Yalçıner, İstanbul: Say Yayınlar1, 8. bs.

Güçbilmez, Beliz; Yılmaz, Şamil (2010). Hasan Ali Toptaş'ın yazıevreninde bir takımyıldızı olarak benzerlik ya da içinden sözlük geçen bir deneme. B. Öztuna (Ed.), Efendime Söyleyeyim Hasan Ali Toptaş Kitabı (s. 185-202) içinde İstanbul: İletişim.

Gümüş, Semih (2013). Ezeli bir acemi. L. Cantek (Ed.), Başlarken Yalnızsın, Bitirdiğinde Daha da Yalnız (s. 57-64) içinde. İstanbul: İletişim.

Jung, Carl Gustav (1952), Önsöz. Jung Psikolojisinin Ana Hatlarl (s. 13-14). İçinde. İstanbul: Say.

Jung, Carl Gustav (1982), Analitik Psikolojinin Temel İlkeleri, çev. Kamuran Şipal, İstanbul: Bozak Yayınlar1. 1. bs.

Jung, Carl Gustav (2016), Analitik Psikoloji Sözlüğü, çev. Nur Nirven, İstanbul: Pinhan Yayınc1lik, 1. bs.

Jung, Carl Gustav (2017), Dört Arketip, çev. Zehra Aksu Yılmazer, İstanbul: Metis Yayınları, 5. bs.

Kale, Senem (2006.02.03). “Taşra sıkıntısı geçer mi?. Radikal Kitap http://kitap.radikal.com.tr/ makale/haber/tasra_sikintisi_gecer_mi-55359. (Erişim Tarihi: 2016.03.14)

Karaduman Okay, Esra (2006). Hayatın tuhaf mucizeleri var. L. Cantek (Ed.), Başlarken Yalnızsın, Bitirdiğinde Daha da Yalnız (s. 209-213) içinde. İstanbul: İletişim.

Korat, Gürsel (2007.06.21). “Toptaş kendi halince yazıyor.” Radikal http://www.radikal.com.tr/ haber.php?haberno=224685 (Erişim Tarihi: 2019.10.31)

Kurt, Tunç (2011). Şair değilim. L. Cantek (Ed.), Başlarken Yalnızsın, Bitirdiğinde Daha da Yalnız (s. 267-269) içinde. İstanbul: İletişim.

Moran, Berna (2008), Edebiyat Kuramları ve Eleştiri, İstanbul: İletişim Yayınları, 18. bs.

Öztunç, Mehmet (2013). Harflere sadece ses olarak bakmam; onlar birer canlıdır gözümde. 
L. Cantek (Ed.), Başlarken Yalnızsın, Bitirdiğinde Daha da Yalnız (s. 77-81) içinde. İstanbul: İletişim.

Saydam, M. Bilgin (2017). Carl Gustav Jung: Nesnel Ruh'un Şamanı. Dört Arketip (s. 7-15) içinde. İstanbul: Metis.

Sazyek, Esra (2013), “Jung Işığında Heba”, Turkish Studies International Periodical For The Languages, Literature and History of Turkish or Turkic, Volume 8/8, Summer, p. 1097 1125.

TDK Türkçe Sözlük. (2005). Ankara: Türk Dil Kurumu Yayınları.

Tokay, Murat (2013). Yeryüzüne bir Kafka yeter, ikinciye gerek yok. L. Cantek (Ed.), Başlarken Yalnızsın, Bitirdiğinde Daha da Yalnız (s. 103-110) içinde. İstanbul: İletişim.

Toptaş, Hasan Ali (2014), Başlarken Yalnızsın, Bitirdiğinde Daha da Yalnız (Söyleşiler Kitabı, İstanbul: İletişim, 2. bs.

Toptaş, Hasan Ali (2014), Sonsuzluğa Nokta, İstanbul: İletişim Yayınları. 4. bs.

Toptaş, Hasan Ali (2019), Harfler ve Notalar, İstanbul: Everest Yayınları, 6. bs.

Ukray, Murat (2015), Jung Psikolojisi Tüm Çalışmaları \& Freud'la Karşılaştırmalı, ed. Taşkın Köksal, Ankara: Yason Yayınları, 1. bs.

Varlık, Mesut (2005). Okuru yok saymak, okurun yararına olan tek şeydir. L. Cantek (Ed.), Başlarken Yalnızsın, Bitirdiğinde Daha da Yalnız (s. 271-277) içinde. İstanbul: İletişim.

Varlık, Mesut (2010), Efendime Söyleyeyim Hasan Ali Toptaş Kitabı, ed. Belce Öztuna, İstanbul: İletişim Yayınları, 1. bs.

Varlık, Mesut (2010). Hasan Ali Toptaş: "Bilginin kendisi değil, buharı muteberdir...” B. Öztuna (Ed.), Efendime Söyleyeyim Hasan Ali Toptaş Kitabı (s. 53-88) içinde. İstanbul: İletişim. 